\title{
Tanggapan Mahasiswa terhadap Pemanfaatan Google Classroom sebagai Media Pembelajaran Online
}

\author{
Suci Ramadhani Arifin ${ }^{\mathrm{a} 1}$, Etha Gustin Merdekawati ${ }^{\mathrm{b} 2}$ \\ a STMIK Dipanegara Makassar \\ Jl. Perintis Kemerdekaan No.KM.9, Tamalanrea Indah, Kec. Tamalanrea, Kota Makassar, Sulawesi Selatan 90245 \\ ${ }^{1}$ suci.arifin@dipanegara.ac.id \\ ${ }^{b}$ Politeknik Informatika Nasional Makassar \\ Jl. Sultan Alauddin No.250, Mangasa, Kec. Tamalate, Kota Makassar, Sulawesi Selatan 90245 \\ 2ethagustinmw@gmail.com
}

\begin{abstract}
Abstrak
Berbagai jenis aplikasi e-learning semakin banyak berkembang saat ini dan yang paling menonjol saat ini adalah Google Classroom. Google Classroom merupakan salah satu platform terbaik untuk meningkatkan alur kerja dosen. Google Classroom kemudian diimplementasikan pada mata kuliah Metode Penelitian Penulisan laporan untuk memfasilitasi dosen dalam memanfaatkan teknologi sebagai alat bantu proses belajar mengajar. Metode yang digunakan dalam penelitian ini adalah metode deskriptif kuantitatif dengan analisis data menggunakan presentase. Instrumen penelitian menggunakan kuesioner dengan subjek penelitian yaitu mahasiswa program D3 Jurusan Manajemen Informatika Politeknik Informatika Nasional Makassar angkatan 2017 yang mengambil mata kuliah Metode Penelitian Penulisan Laporan. Mahasiswa menunjukkan tanggapan yang baik terhadap pemanfaatan Google Classroom dalam proses belajar mengajar pada mata kuliah Metode Penelitian Penulisan Laporan dengan tingkat persentase sebesar 79\% yang termasuk ke dalam kategori sangat positif.
\end{abstract}

Kata kunci: Google Suite for Education, Google Classroom, e-Learning, Mahasiswa, Tanggapan Mahasiswa

\section{Students' Responses on Google Classroom Utilizing as an Online Learning Media}

\begin{abstract}
Various types of e-learning applications are increasingly developing at this time and the most prominent at this time is Google Classroom. Google Classroom is one of the best platforms for improving lecturer workflows. Google Classroom was then implemented in the Research Methods Writing report course to facilitate lecturers in utilizing technology as a teaching aid. The method used in this research is a quantitative descriptive method with data analysis using percentages. The research instrument used a questionnaire with research subjects, namely D3 students of the Department of Information Management Makassar National Informatics Polytechnic class of 2017 who took the Research Method Writing Report. Students showed a good response to the use of Google Classroom in the teaching and learning process in the Report Writing Method Research course with a percentage rate of 79\% which was included in the very positive category.
\end{abstract}

Keywords: Google Suite for Education, Google Classroom, e-Learning, Students, Students' Responses

\section{Pendahuluan}

E-Learning merupakan suatu media berbagi informasi tentang ilmu pengetahuan yang memungkinkan tersampaikannya bahan ajar ke siswa dengan menggunakan media internet, intranet atau media jaringan komputer lain [1]. E-Learning berarti pembelajaran dengan bantuan layanan elektronik, khususnya perangkat lunak komputer [2].

Berbagai jenis aplikasi e-learning semakin banyak berkembang saat ini dan yang paling menonjol saat ini adalah Google Classroom [3]. Google Classroom adalah teknologi terbaru yang diperkenalkan oleh Google Apps for
Education pada tahun 2014. Google Classroom memfasilitasi para dosen untuk membuat dan mengatur tugas dengan cepat, memberikan umpan balik secara efisien, dan berkomunikasi dengan kelas dengan muda [4], $[5]$.

Google Classroom merupakan salah satu platform terbaik untuk meningkatkan alur kerja dosen. Google Classroom dimaksudkan untuk membantu para dosen mengelola tugas mahasiswa dalam lingkungan tanpa kertas (paperless) dengan memanfaatkan fasilitas Google Docs, Google Drive, dan aplikasi lainnya [6].

Aplikasi Google Classroom memiliki kelebihan diantaranya; gratis, mudah digunakan oleh pengguna 
(dosen maupun mahasiswa), terintegrasi dengan media sosial seperti Facebook dan Twitter, serta aplikasi Google lainnya, misalnya Google Form, Google Drive, Google Doc, Google Slides, You Tube, dan lainnya [7], [8]. Sudarsana et al. [9] menyebutkan kelemahan aplikasi Google Classroom adalah mengharuskan mahasiswa untuk memiliki gadget (laptop/tablet/smartphone) yang mendukung fitur Google Classroom, namun tidak semua mahasiswa memiliki perangkat tersebut.

Penelitian terdahulu mengenai e-learning atau pembelajaran online telah banyak dilaksanakan, namun jumlah makalah penelitian yang berfokus pada Google Classroom sebagai media pembelajaran masih terbatas [10]. Salah satu penelitian terbaru dilaksanakan oleh Utami [11] dengan tujuan untuk mengetahui respons mahasiswa terhadap pembelajaran menggunakan Google Classroom pada matakuliah Psikologi Pembelajaran Matematika. Hasil penelitian Utami menunjukan bahwa pembelajaran Google Classroom mendapatkan respon yang baik dari mahasiswa, sehingga dapat digunakan untuk pembelajaran pada matakuliah Psikologi Pembelajaran Matematika ataupun pada mata kuliah yang lain. Jakkaew \& Hemrungrote [12] memanfaatkan model UTAUT 2 menyelidiki faktor-faktor utama yang mempengaruhi implementasi Google Classroom dalam mata kuliah tertentu. Temuan utama penelitian Jakkaew \& Hemrungrote mendukung fakta bahwa Google Classroom dapat meningkatkan kemampuan kognitif siswa dalam pembelajaran mandiri. Dalam domain belajar mandiri dan pengembangan diri, sebuah penelitian dilakukan oleh Hemrungrote, Jakkaew, \& Assawaboonmee [13] yang lebih menekankan pada peranan Google Classroom sebagai alat pembelajaran mandiri dalam mata kuliah yang telah ditentukan sebelumnya. Hasil penelitian membuktikan siswa puas terhadap penggunaan Google Classroom karena mudah untuk digunakan, dan kepraktisannya dalam menyelesaikan tugas yang diberikan.

Politeknik Informatika Nasional Makassar adalah salah satu perguruan tinggi yang telah menggunakan Google Classroom dalam proses pembelajaran khususnya dalam mata kuliah Metode Penelitian Penulisan Laporan. Penggunaan Google Classroom telah diterapkan mulai dari awal semester ganjil periode 2019/2020 pada awal Oktober 2019.

Tujuan penelitian ini adalah untuk mengetahui tanggapan mahasiswa terhadap pemanfaatan Google Classroom dalam proses belajar mengajar pada mata kuliah Metode Penelitian Penulisan Laporan.

\section{METODE PENELITIAN}

Cara mudah agar format makalah Anda sesuai dengan format makalah yang kami perlukan, gunakan dokumen ini sebagai template dan ketik teks Anda di dalamnya.

Metode yang digunakan dalam penelitian ini adalah metode deskriptif kuantitatif dengan analisis data menggunakan presentase. Penelitian deskriptif kuantitatif merupakan usaha sadar dan sistematis untuk memberikan jawaban terhadap suatu masalah dan/atau mendapatkan informasi lebih dalam dan luas terhadap suatu fenomena secara detail [14].
Subjek penelitian yaitu mahasiswa program D3 Jurusan Manajemen Informatika Politeknik Informatika Nasional Makassar angkatan 2017 yang mengambil mata kuliah Metode Penelitian Penulisan Laporan sebanyak 18 responden.

Penelitian ini dilakukan dengan cara membuat kelas di Google Classroom terlebih dahulu. Setelah itu, dosen meminta mahasiswa bergabung ke dalam kelas yang dibuat melalui kode kelas dari Google Classroom yang telah dibuat. Materi pembelajaran dapat diunggah dengan menggunakan pilihan pada "About" di Google Classroom. Kemudian materi diunggah melalui "Add Materials". Untuk memberitahukan siswa jika materi telah diunggah, maka dapat menggunakan pilihan "Stream" di Google Classroom, kemudian pilih "Announcement" pada "+". Untuk menambahkan tugas dapat memilih "Assigments" pada "+". Untuk menambahkan pertanyaan atau kuesioner pada Google Classroom dapat memilih "Question" pada "+”. Melalui button yang dimiliki oleh Google Classroom, aktivitas mahasiswa dapat dilihat dari laporan yang diberikan pada kelas Google Classroom. Apabila mahasiswa telah mengunggah tugas yang dikerjakan atau hasil kuesioner yang terdapat di Google Classroom, maka ada notifikasi "Done" pada halaman kelas Google Classroom [11], [15].

Teknik pengumpulan data menggunakan Kuesioner yang diadopsi dari penelitian Utami [11]. Variabel dalam penelitian ini terdiri atas variabel Penerimaan mahasiswa pada kemudahan Google Classroom dan variabel performa Google Classroom yang terdiri atas 14 indikator pertanyaan yang diukur menggunakan skala Guttman secara tradisional (cross sectional) [16] untuk mendapatkan jawaban yang tegas terhadap suatu permasalahan yang ditanyakan. Dalam penelitian ini jawaban positif "Setuju" diberi skor 1 dan jawaban negatif "Tidak Setuju" diberi skor 0. Kuesioner penelitian dapat dilihat pada Tabel 1.

TABEL I

KUESIONER PENELITIAN

\begin{tabular}{|c|c|}
\hline Variabel & Indikator \\
\hline $\begin{array}{l}\text { Penerimaan } \\
\text { mahasiswa pada } \\
\text { kemudahan Google } \\
\text { Classroom }\end{array}$ & $\begin{array}{l}\text { 1. Menggunakan Google Classroom } \\
\text { memungkinkan dalam menyelesaikan } \\
\text { tugas lebih cepat } \\
\text { 2. Google Classroom meningkatkan } \\
\text { performa pembelajaran mahasiswa } \\
\text { 3. Google Classroom dapat } \\
\text { meningkatkan produktivitas dalam } \\
\text { pembelajaran } \\
\text { 4. Google Classroom sangat berguna } \\
\text { dalam proses pembelajaran } \\
\text { 5. Kemudahan dalam mengakses Google } \\
\text { Classroom } \\
\text { 6. Kemudahan dalam penggunaan } \\
\text { Google Classroom sesuai yang } \\
\text { diinginkan } \\
\text { 7. Google Classroom menarik perhatian } \\
\text { mahasiswa dalam pembelajaran } \\
\text { 8. Google Classroom memungkinkan } \\
\text { mahasiswa mendapatkan umpan balik } \\
\text { secara lebih cepat } \\
\text { Mahasiswa senang menggunakan } \\
\text { Google Classroom dalam } \\
\text { pembelajaran }\end{array}$ \\
\hline
\end{tabular}




\begin{tabular}{|c|c|c|}
\hline \multicolumn{2}{|c|}{ Variabel } & Indikator \\
\hline \multirow[t]{5}{*}{$\begin{array}{l}\text { Performa } \\
\text { Classroom }\end{array}$} & Google & $\begin{array}{l}\text { 10. Tampilan Google Classroom sangat } \\
\text { jelas dan mudah dipahami }\end{array}$ \\
\hline & & $\begin{array}{l}\text { 11. Dengan Google Classroom, } \\
\text { memperoleh pengumuman, materi } \\
\text { maupun pengumpulan tugas menjadi } \\
\text { lebih fleksibel }\end{array}$ \\
\hline & & $\begin{array}{l}\text { 12. Google Classroom memudahkan saya } \\
\text { untuk menyimpan dokumen materi } \\
\text { maupun tugas yang penting }\end{array}$ \\
\hline & & $\begin{array}{l}\text { 13. Google Classroom memudahkan saya } \\
\text { untuk menyimpan dokumen materi } \\
\text { maupun tugas yang penting (real time) }\end{array}$ \\
\hline & & $\begin{array}{l}\text { 14. Google classroom dapat menghemat } \\
\text { waktu dan biaya }\end{array}$ \\
\hline
\end{tabular}

Kemudahan dalam menggunakan Google Classroom meliputi perilaku mahasiswa dalam menggunakan Google Classroom, implementasi Google Classroom dalam pembelajaran dan ketersediaan infrastruktur untuk menggunakan Google Classroom. Sedangkan performa Google Classroom berkaitan dengan penampilan, cara kerja maupun fasilitas yang diberikan untuk penggunanya [11].

Data yang diperoleh akan dianalisis menggunakan analisis deskriptif kuantitatif dalam bentuk persentase untuk lebih memudahkan dalam membaca dan memahami data. Urutan langkah yang dilakukan dimulai dengan menghitung skor perolehan tiap indikator. Kemudian menghitung persentase jawaban dari tiap indikator. Setelah menghitung persentase jawaban tiap indikator, kemudian ditarik kesimpulan terhadap hasil penelitian.

Penelitian ini menggunakan pedoman dari Sugiyono [17] yang menyatakan bahwa semakin tinggi persentase responden maka semakin baik pula persepsi responden tersebut [18]. Ketentuan skala persentase yang digunakan untuk menyimpulkan data hasil penelitian dapat dilihat pada Tabel 2.

TABEL III

KRITERIA INTERPRETASI SKOR

\begin{tabular}{|c|c|l|}
\hline No & Rentang Skor (\%) & \multicolumn{1}{|c|}{ Kategori } \\
\hline $\mathbf{1}$ & $76-100$ & Sangat Positif \\
\hline $\mathbf{2}$ & $51-75$ & Positif \\
\hline $\mathbf{3}$ & $26-50$ & Negatif \\
\hline $\mathbf{4}$ & $1-25$ & Sangat Negatif \\
\hline
\end{tabular}

\section{HASIL DAN PEMBAHASAN}

Hasil yang diperoleh dari instrumen penelitian (kuesioner) kemudian dipindahkan ke dalam tabel distribusi frekuensi yang ditunjukkan pada Tabel 3. Data kemudian dianalisis untuk mengetahui tanggapan mahasiswa terhadap pemanfaatan Google Classroom dalam proses belajar mengajar pada mata kuliah Metode Penelitian Penulisan Laporan yang mengacu pada empat belas (14) indikator yang dikembangkan oleh [8] yang terbagi ke dalam dua (2) variabel, yaitu Penerimaan mahasiswa pada kemudahan Google Classroom dan Performa Google Classroom.
TABEL III

TABEL Distribusi FreKUENSI TANGGAPAN MAHASISWA

\begin{tabular}{|c|c|c|}
\hline Indikator & Persentase & Kategori \\
\hline $\begin{array}{l}\text { 1. Menggunakan Google Classroom } \\
\text { memungkinkan dalam } \\
\text { menyelesaikan tugas lebih cepat }\end{array}$ & $78 \%$ & $\begin{array}{l}\text { Sangat } \\
\text { Positif }\end{array}$ \\
\hline $\begin{array}{l}\text { 2. Google Classroom meningkatkan } \\
\text { performa pembelajaran } \\
\text { mahasiswa }\end{array}$ & $94 \%$ & $\begin{array}{l}\text { Sangat } \\
\text { Positif }\end{array}$ \\
\hline $\begin{array}{l}\text { 3. Google Classroom dapat } \\
\text { meningkatkan produktivitas } \\
\text { dalam pembelajaran }\end{array}$ & $56 \%$ & Positif \\
\hline $\begin{array}{l}\text { 4. Google Classroom sangat berguna } \\
\text { dalam proses pembelajaran }\end{array}$ & $100 \%$ & $\begin{array}{l}\text { Sangat } \\
\text { Positif }\end{array}$ \\
\hline $\begin{array}{l}\text { 5. Kemudahan dalam mengakses } \\
\text { Google Classroom }\end{array}$ & $83 \%$ & $\begin{array}{l}\text { Sangat } \\
\text { Positif }\end{array}$ \\
\hline $\begin{array}{l}\text { 6. Kemudahan dalam penggunaan } \\
\text { Google Classroom sesuai yang } \\
\text { diinginkan }\end{array}$ & $50 \%$ & Negatif \\
\hline $\begin{array}{l}\text { 7. Google Classroom menarik } \\
\text { perhatian mahasiswa dalam } \\
\text { pembelajaran }\end{array}$ & $83 \%$ & $\begin{array}{l}\text { Sangat } \\
\text { Positif }\end{array}$ \\
\hline $\begin{array}{l}\text { 8. Google Classroom } \\
\text { memungkinkan mahasiswa } \\
\text { mendapatkan umpan balik secara } \\
\text { lebih cepat }\end{array}$ & $78 \%$ & $\begin{array}{l}\text { Sangat } \\
\text { Positif }\end{array}$ \\
\hline $\begin{array}{l}\text { 9. Mahasiswa senang menggunakan } \\
\text { Google Classroom dalam } \\
\text { pembelajaran } \\
\end{array}$ & $72 \%$ & Positif \\
\hline $\begin{array}{l}\text { 10. Tampilan Google Classroom } \\
\text { sangat jelas dan mudah dipahami }\end{array}$ & $94 \%$ & $\begin{array}{l}\text { Sangat } \\
\text { Positif }\end{array}$ \\
\hline $\begin{array}{l}\text { 11. Dengan Google Classroom, } \\
\text { memperoleh pengumuman, materi } \\
\text { maupun pengumpulan tugas } \\
\text { menjadi lebih fleksibel }\end{array}$ & $89 \%$ & $\begin{array}{l}\text { Sangat } \\
\text { Positif }\end{array}$ \\
\hline $\begin{array}{l}\text { 12. Google Classroom memudahkan } \\
\text { saya untuk menyimpan dokumen } \\
\text { materi maupun tugas yang penting }\end{array}$ & $83 \%$ & $\begin{array}{l}\text { Sangat } \\
\text { Positif }\end{array}$ \\
\hline $\begin{array}{l}\text { 13. Google Classroom memudahkan } \\
\text { saya untuk menyimpan dokumen } \\
\text { materi maupun tugas yang penting } \\
\text { (real time) }\end{array}$ & $78 \%$ & $\begin{array}{l}\text { Sangat } \\
\text { Positif }\end{array}$ \\
\hline $\begin{array}{l}\text { 14. Google classroom dapat } \\
\text { menghemat waktu dan biaya }\end{array}$ & $61 \%$ & Positif \\
\hline RATA-RATA & $79 \%$ & $\begin{array}{l}\text { Sangat } \\
\text { Positif }\end{array}$ \\
\hline
\end{tabular}

Hasil analisis data menunjukkan tanggapan mahasiswa terhadap pemanfaatan Google Classroom dalam proses belajar mengajar pada mata kuliah Metode Penelitian Penulisan Laporan dalam kategori sangat positif sampai sangat negatif dengan rincian sebagai berikut.

Berdasarkan Tabel 3, dapat dilihat bahwa mahasiswa menunjukkan tanggapan yang baik terhadap sepuluh (10) indikator yang termasuk ke dalam kategori positif yaitu, indikator nomor 1,2,4,5,7,8,10,11,12,13. Mahasiswa sangat setuju bahwa pemanfaatan Google Classroom dalam proses belajar mengajar pada mata kuliah Metode Penelitian Penulisan Laporan memungkinkan mahasiswa dalam menyelesaikan tugas lebih cepat, meningkatkan performa pembelajaran mahasiswa, pemanfaatan Google Classroom sangat berguna dalam proses pembelajaran serta mudahnya mengakses Google Classroom. Google Classroom juga dianggap mampu menarik perhatian mahasiswa dalam pembelajaran dan memungkinkan mahasiswa mendapatkan umpan balik secara lebih cepat. 
Selain itu, tampilan Google Classroom sangat jelas dan mudah dipahami oleh mahasiswa. Google Classroom juga memberikan kemudahan dalam memperoleh pengumuman, materi dan pengumpulan tugas menjadi lebih fleksibel. Google Classroom juga memudahkan mahasiswa untuk menyimpan dokumen materi maupun tugas yang penting secara real time.

Selain itu data hasil penelitian pada Tabel 3 juga menunjukkan bahwa mahasiswa memiliki tanggapan yang baik terhadap tiga (3) indikator yang termasuk ke dalam kategori positif yaitu indikator nomor 3,9, dan 14 Berdasarkan hal tersebut, mahasiswa setuju bahwa pemanfaatan Google Classroom dalam proses belajar mengajar pada mata kuliah Metode Penelitian Penulisan Laporan dapat meningkatkan produktivitas dalam pembelajaran. Mahasiswa juga senang menggunakan Google Classroom dalam pembelajaran dan mahasiswa menganggap bahwa pemanfaatan Google classroom dapat menghemat waktu dan biaya.

Dari empat belas (14) indikator penelitian, terdapat satu (1) indikator yang masuk ke dalam kategori negatif yaitu indikator nomor 6 "Kemudahan dalam penggunaan Google Classroom sesuai yang diinginkan". Berdasarkan hal tersebut, dapat disimpulkan bahwa mahasiswa tidak setuju terhadap pernyataan tersebut.

\section{KESIMPULAN}

Secara keseluruhan, mahasiswa menunjukkan tanggapan yang baik terhadap pemanfaatan Google Classroom dalam proses belajar mengajar pada mata kuliah Metode Penelitian Penulisan Laporan dengan tingkat persentase sebesar 79\% yang termasuk ke dalam kategori sangat positif.

\section{DAFTAR PUSTAKA}

[1] F. T. S. Butarbutar and Y. Haryanto, "Kajian Signifikansi Faktor Yang Mempengaruhi Penggunaan e-Learning Pada Siswa SMK Global Informatika Tangerang," Jurnal RESTI (Rekayasa Sistem dan Teknologi Informasi), vol. 1, no. 1, pp. 9-18, Jul. 2017, doi: 10.29207/resti.v1i1.13.

[2] A. Wijaya, "Analysis of Factors Affecting the Use of Google Classroom to Support Lectures," The 5th International Conference on Information Technology and Engineering Application (ICIBA2016), Feb. 2016, Accessed: Dec. 27, 2019 [Online]. Available: http://eprints.binadarma.ac.id/2777/.

[3] S. Bhat, R. Raju, A. Bikramjit, and R. D’Souza, "Leveraging ELearning through Google Classroom: A Usability Study," Journal of Engineering Education Transformations, vol. 31, no. 3, pp. 129-135-135, Jan. 2018, doi: 10.16920/jeet/2018/v31i3/120781.

[4] I. N. M. Shaharanee, J. M. Jamil, and S. S. M. Rodzi, "The Application of Google Classroom as a Tool for Teaching and Learning," Journal of Telecommunication, Electronic and Computer Engineering (JTEC), vol. 8, no. 10, pp. 5-8-8, Dec. 2016

[5] I. N. M. Shaharanee, J. M. Jamil, and S. S. M. Rodzi, "Google classroom as a tool for active learning," AIP Conference Proceedings, vol. 1761, no. 1, p. 020069, Aug. 2016, doi: $10.1063 / 1.4960909$

[6] S. Iftakhar, "Google classroom: what works and how?," Journal of Education and Social Sciences, vol. 3, no. 1, pp. 12-18, Feb. 2016.

[7] R. Ramadhani, R. Umam, A. Abdurrahman, and M. Syazali, "The Effect of Flipped-Problem Based Learning Model Integrated With LMS-Google Classroom for Senior High School Students," Journal for the Education of Gifted Young Scientists, vol. 7, no. 2, Art. no. 2, Jun. 2019, doi: 10.17478/jegys.548350.
[8] K. A. Azhar and N. Iqbal, "Effectiveness of Google Classroom Teachers' Perceptions," LV, vol. 2, no. 2, Art. no. 2, Aug. 2018.

[9] I. K. Sudarsana, I. B. M. A. Putra, I. N. T. Astawa, and I. W. L. Yogantara, "The use of Google classroom in the learning process," J. Phys.: Conf. Ser., vol. 1175, p. 012165, Mar. 2019, doi: 10.1088/1742-6596/1175/1/012165.

[10] R. A. S. Al-Maroof and M. Al-Emran, "Students Acceptance of Google Classroom: An Exploratory Study using PLS-SEM Approach," International Journal of Emerging Technologies in Learning (iJET), vol. 13, no. 06, Art. no. 06, May 2018.

[11] R. Utami, "Analisis Respon Mahasiswa terhadap Penggunaan Google Classroom pada Mata Kuliah Psikologi Pembelajaran Matematika," PRISMA, Prosiding Seminar Nasional Matematika, vol. 2, pp. 498-502, Feb. 2019.

[12] P. Jakkaew and S. Hemrungrote, "The use of UTAUT2 model for understanding student perceptions using Google Classroom: A case study of Introduction to Information Technology course," 2017 International Conference on Digital Arts, Media and Technology (ICDAMT), pp. 205-209, 2017, doi: 10.1109/ICDAMT.2017.7904962.

[13] S. Hemrungrote, P. Jakkaew, and S. Assawaboonmee, "Deployment of Google Classroom to enhance SDL cognitive skills: A case study of introduction to information technology course," in 2017 International Conference on Digital Arts, Media and Technology (ICDAMT), Chiang Mai, Thailand, 2017, pp. 200-204, doi: 10.1109/ICDAMT.2017.7904961.

[14] M. Yusuf, Metode Penelitian Kuantitatif, Kualitatif \& Penelitian Gabungan. Jakarta: Prenada Media, 2016.

[15] F. I. Gunawan and S. G. Sunarman, "PENGEMBANGAN KELAS VIRTUAL DENGAN GOOGLE CLASSROOM DALAM KETERAMPILAN PEMECAHAN MASALAH (PROBLEM SOLVING) TOPIK VEKTOR PADA SISWA SMK UNTUK MENDUKUNG PEMBELAJARAN," Prosiding Seminar Nasional Pendidikan Matematika Etnomatnesia, vol. 0 , no. 0, Feb. 2018, Accessed: Dec. 27, 2019. [Online]. Available: http://jurnal.ustjogja.ac.id/index.php/etnomatnesia/article/view/2 334.

[16] Iskani, "PENGUKURAN SKALA GUTTMAN SECARA TRADISIONAL (CROSS SECTIONAL)," e-Journal Politeknik Tegal, Accessed: Mar. 06, 2020. [Online]. Available: http://ejournal.poltektegal.ac.id/index.php/informatika/article/do wnloadSuppFile/832/345.

[17] Sugiyono, Metode penelitian pendidikan: (pendekatan kuantitatif, kualitatif dan $R \& D$ ). Alfabeta, 2013.

[18] T. A. Aslamiyah, P. Setyosari, and H. Praherdhiono, "BLENDED LEARNING DAN KEMANDIRIAN BELAJAR MAHASISWA TEKNOLOGI PENDIDIKAN," Jurnal Kajian Teknologi Pendidikan, vol. 2, no. 2, pp. 109-114, Jun. 2019, doi: 10.17977/um038v2i22019p109. 